Ilmu Pertanian (Agricultural Science)

Vol. 1 No.3 December, 2016 : 123-129

Available online at http://journal.ugm.ac.id/jip

DOI: doi.org/10.22146/ipas.11217

ILMU PERTANIAN
(AGRICULTURAL SCIENCE)

\title{
The Export Strategy of PT. Dagsap Endura Eatore Yogyakarta for Entering Asean International Market
}

\author{
Khusaini Wijayanto*, Dwidjono Hadi Darwanto, Lestari Rahayu Waluyati \\ Department of Agricultural Socio Economics, Faculty of Agriculture, Universitas Gadjah Mada \\ Jln. Flora no. 1, Bulaksumur, Sleman, Yogyakarta 5528, Indonesia \\ *Corresponding email: husein_dtpugm@yahoo.com
}

Received: $16^{\text {th }}$ May 2016 ; Revised: $27^{\text {th }}$ June 2016 ; Accepted: $21^{\text {st }}$ August 2017

\begin{abstract}
This study aimed to determine the position of PT. Dagsap Endura Eatore Yogyakarta and to formulate the export strategy to enter the international market of ASEAN. The primary and secondary data were used in this study. The SWOT analysis, consisted of four indicators i.e strengths, weakness, opportunities, and threats, was used for analysis data. The results showed that the total of weighting score for force factor of PT. Dagsap Endura Yogyakarta Eatore was 4.45; the vulnerability factor was 4.07; odds factor was 4.70; and threats factor was 4.11. The current PT. Dagsap Endura Eatore Yogyakarta is in quadrant 1 (one) SWOT matrix that supports an aggressive growth policy (Growth Oriented Strategy). Export strategy for PT. Dagsap Endura Eatore Yogyakarta should use the power, so that it can seize the export opportunities to enter the international market of ASEAN.
\end{abstract}

Keywords: ASEAN International Markets, Export Strategy, PT. Dagsap Endura Eatore Yogyakarta

\section{INTRODUCTION}

In early 2016, ASEAN countries have undergone a phase of economic changes by having a single market and production basis, called ASEAN Economic Community (AEC). AEC is a form of economic integration among ASEAN countries in order to obtain the ASEAN stable economy, profitable and highly competitive. The AEC is an area of free trade in Southeast Asia which is based on four pillars: 1) a single market and production base, 2) a region with high competitiveness in the economy, 3 ) equitable economic development and 4) full integration in the global economy. In addition, there will be the elimination of tariffs to get the flow of goods /services/investments/free capital among ASEAN countries (Gaspersz, 2014).

Free trade makes the country easy to conduct cross-country trade transactions. One of the crosscountry transactions model conducted by business actors is through exports. In order for the products offered by the company can compete and gain the profits then the company must be able to set the strategy in marketing (Darmayani et al., 2014). Economic growth is getting better from year to year and the increase in the population of Indonesia causes an increase in the number of needs or cumsumption of animal protein such as meat, milk, and eggs (Marhendra et al., 2014). Sadaghiania et al. (2011) stated the increasing levels of globalization and international competition, managers are facing ever more complex strategic decisions. Often, foremost among these are decisions relating to the choice of entry strategy in export markets. Selection of an appropriate entry strategy is a critical and indispensable component of the strategic decision a firm has to make when investing overseas.

For companies which are just undergoing on an abroad marketing, the export marketing is the first step to respond to abroad market opportunities apart from its domestic market. Marketers make exports overseas markets as the target and rely on domestic production to supply the overseas market with a focus on export opportunities and take advantage of their experience in the country. The existence of opportunities and challenges in export marketing which influences the changes in the marketing environment both internal and external environments makes the need for a good export strategy becomes an urgent matter and important to face the intensity of the higher competitiveness. 
Based on that idea, the authors were interested to undergo a research on the export strategy of processed chicken meat products, namely chicken nuggets and chicken sausage of PT. Dagsap Endura Eatore Yogyakarta in entering the ASEAN international market. The existence of opportunities and challenges in export marketing that would be done by PT. Dagsap Endura Eatore Yogyakarta required a good export strategy, so that the company's products could compete in the ASEAN international market. Besides, the company was also required to be responsive toward the changes in the environment of ASEAN international market in order to determine the company's competitiveness as an export strategy in entering the ASEAN international market.

Ichwanda et al. (2015) applied method of SWOT analysis and concluded the company's greatest strenght was secure quality of PT. Petrokimia Gresik's product, while the company's biggest weakness was demand to fulfill subsidy necessary. The company's greatest opportunities is high demand in South Asia, while the biggest threat to the company come from government who don't give their support to export. Charity et al. (2016) applied the analytical method used is SWOT (Strenghts, Weakness, Opportunities, and Threats) analyisis, with the analysis of EFAS, IFAS, IE and SWOT matrix on PT Telekomunikasi Indonesia. The result indicated PT Telekomunikasi Indonesia has applied the right strategy with strategy of developing, but to support the company's expansion activities in Myanmar it need to do some alternative strategies that have been formulated based on the vision, mission, internal analysis and external analysis.

This study aimed to determine the position of PT. Dagsap Endura Eatore Yogyakarta and to formulate the export strategy to enter the international market of ASEAN.

\section{MATERIALS AND METHODS}

\section{Respondents Determination}

The basic method chosen to analyze the data was descriptive analysis. The data are from survey (interview) and company document. Interviewees in this study were the stakeholder or people who had an interest in PT. Dagsap Endura Eatore Yogyakarta included top management (top management), middle management (middle management), and lower management/line (low management). The taken samples were 30 people consisting people of the company (Planning and Production Manager, Marketing Manager, Production Supervisor, Warehouse Supervisor, Head of Production, Head of
Accounting and Finance, the Head of HR and Employee). The respondent determination was done in a non probabilistic, with the consideration that people who knew most about the condition of PT. Dagsap Endura Eatore Yogyakarta were the company's people itself.

\section{Data Collection}

The main instrument used for data collection was a human instrument. In other words, the research's tool was the researchers itself. This was done in order to make the instrument could determine the focus of the research, select informants as data source, collect the data, assess the data quality, analysis the data, interpret the data, and make conclusions of the findings. The role of the researcher was as a key instrument. The role of researchers is very complex, beside as a planner, he also works as a data collector, data interpreter, and in the end he has to act as reporter of the research result itself (Assauri, 1990).

The data used in the SWOT analysis was the internal data of the company, i.e recent data about the internal state of the company that covered the strengths and the weakness of the company, as well as external data company which was the data about recent external conditions beyond the company that included opportunities and the threats of companies in the ASEAN international market.

\section{Data Analysis}

The weighting to internal and external factors of PT. Dagsap Endura Eatore Yogyakarta was as followed:

1.) Determining factors of the strengths, weaknessess, opportunities and threats of the company respectively of 5-10 items. 2.) Giving weight of each factor with a scale that started from the highest score 1.0 (for the most important factor) to the lowest score 0.0 (for a less important factor). The total weight should not exceed 1.0. 3.) Determining the rating for each factor. The rating was started from $1=$ Very Low, 2 =Low, $3=$ Moderate, $4=$ High, $5=$ Very High. 4.) Switching weights for each defining factor with the priorities important factor (rating) which its value had been chosen, so that a certain amount could be obtained. The result was a weighting score for each internal and external factor. 5.) The total value of the results of Weights (W) $x$ Rating (R) showed how companies reacted toward their internal and external strategic factors. This value could be used to determine the company's current position of the quadrant in the SWOT matrix, so that the alternative strategy could be identified. 
Table 1. SWOT Matrix

\begin{tabular}{lll}
\hline \multicolumn{1}{c}{ IFAS } & $\begin{array}{l}\text { Strengths (S) } \\
\text { determine 5-10 of internal strengths fac- } \\
\text { tors }\end{array}$ & $\begin{array}{l}\text { Weakness (W) } \\
\text { determine 5-10 internal weakness } \\
\text { factors }\end{array}$ \\
\hline $\begin{array}{l}\text { Opportunities (O) } \\
\text { determine 5-10 internal opportunities } \\
\text { factors }\end{array}$ & $\begin{array}{l}\text { Quadrant I } \\
\text { Supports an aggressive strategy }\end{array}$ & Quadrant III \\
$\begin{array}{l}\text { Threats (T) } \\
\text { determine 5-10 internal threats } \\
\text { factors }\end{array}$ & Quadrant II & Supports turn-around strategy \\
\hline
\end{tabular}

Remarks: 1. Quadrant I: is very favorable situation. The Company has the opportunities and strengths, so that it can take advantage of the available opportunities and strengths. The applied strategy should be in this circumstance is to support the aggressive growth policies (Growth Oriented Strategy); 2. Quadrant II: in spite of all threats, companies still have the power in terms of internal. The applied strategy should use the force to take advantage of long-term opportunities by using diversification strategy (product or market); 3. Quadrant III: the company faces enormous market opportunities, on the other hand, it faces several constraints / internal weaknessess. Here, the focus of the strategy is to minimize the internal weakness, so that it can seize the market opportunities better; 4. Quadrant IV: is a very unfavorable situation, the company faces a variety of threats and internal weakness. The strategy is how to reduce threats and vulnerabilities.

\section{SWOT Matrix}

SWOT matrix produced four possible alternatives strategies showed in Table 1.

\section{RESULT AND DISCUSSION}

\section{Company Profile}

PT. Dagsap Endura Eatore Yogyakarta is a frozen food company that produces chicken meat processed products of large scale, such as chicken nuggets and chicken sausage. The company is located at $\mathrm{Km} 14$ Jalan Wates Kalijoho, Argosari, Sedayu, Bantul, Yogyakarta. PT. Dagsap Endura Eatore Yogyakarta headed by a Plan Manager who led several management including purchasing manager, production manager and PPIC, QC \& QA manager, warehouse manager, maintenance manager, and human resource manager. PT. Dagsap Endura Eatore committed to implement the Food Safety Management System in the production process. PT. Dagsap Endura Eatore also meets the standards and procedures good food preparations in accordance with the food safety has been proved by HACCP (Hazard Analysis Critical Control Point) and GMP (Good Manufacturing Practices).

\section{Weighting Results of Internal Factors}

Based on the observations and interviews regarding to the company's internal environment, the factors which became the strengths of PT. Dagsap Endura Eatore Yogyakarta could be identified. The weighting results and rating for each internal strengths factor of PT. Dagsap Endura Eatore Yogyakarta were shown in Table 2.

Based on observations and interviews regarding to the company's internal environment, the factor that became weakness of PT. Dagsap Endura Eatore Yogyakarta could be identified. The weighting results and rating for each factor of internal weakness of PT. Dagsap Endura Eatore Yogyakarta were shown in Table 3.

\section{Weighting Results of External Factors}

Based on the observations and interviews regarding to the company's external environment, the opportunities factor of PT. Dagsap Endura Eatore Yogyakarta in entering the ASEAN international market could be identified. The weighting results and rating for each factor external opportunities PT. Dagsap Endura Eatore Yogyakarta were shown in Table 4.

Based on the observations and interviews regarding to the company's external environment, the factors that posed a threats toward PT. Dagsap Endura Eatore Yogyakarta in entering the ASEAN international market could be identified. The weighting results and ratings for external threats factors of PT. Dagsap Endura Eatore Yogyakarta were shown in Table 5.

\section{Company Positioning}

According to Sopian (2010), mapping the results analysis of internal and external environmental factors of a company in the form of total score was needed in order to evaluate the strategy undertaken by the manufacturer. The result of the strengths and weakness analysis were generated by subtracting the amount of weight to strengths with the weighted to weakness, while the result of the analysis of opportunities and threats was generated by means of reducing the amount of odds weight with the amount of threats weight.

The results of quantitative analysis of the external factors included the opportunities and threats of the company, which demonstrated a total score of opportunities was 4.70 , and the total score of weakness analysis was 4.11 which meant that opportunities 
Table 2. The Weighting of StrengthsFactor of PT. Dagsap Endura Eatore Yogyakarta

\begin{tabular}{|c|c|c|c|c|c|c|c|c|}
\hline \multirow{2}{*}{ No } & \multirow{2}{*}{ Strengths } & \multirow{2}{*}{$\begin{array}{l}\text { Weight } \\
\text { (W) }\end{array}$} & \multicolumn{5}{|c|}{ Rating (R) } & \multirow{2}{*}{ Score $(\mathrm{W} \times \mathrm{R})$} \\
\hline & & & 1 & 2 & 3 & 4 & 5 & \\
\hline & $\begin{array}{l}\text { The ability of the production process and the } \\
\text { continuity of production }\end{array}$ & 0.13 & & & & & $\mathrm{x}$ & 0.65 \\
\hline & $\begin{array}{l}\text { The ability of the staffs and employees in carrying } \\
\text { out the production work }\end{array}$ & 0.09 & & & & $\mathrm{x}$ & & 0.36 \\
\hline 3 & $\begin{array}{l}\text { Management capability and experience in executing } \\
\text { marketing activities }\end{array}$ & 0.09 & & & & $\mathrm{x}$ & & 0.36 \\
\hline 4 & Ability in determining the markettarget & 0.07 & & & & $\mathrm{x}$ & & 0.28 \\
\hline 5 & Mastery of the domestic market & 0.07 & & & $\mathrm{x}$ & & & 0.21 \\
\hline 6 & $\begin{array}{l}\text { The use of modern machines / semi-robotic for the } \\
\text { large capacityproduction }\end{array}$ & 0.12 & & & & & $\mathrm{x}$ & 0.60 \\
\hline 7 & Distribution capability and means of transport & 0.08 & & & & $\mathrm{x}$ & & 0.32 \\
\hline & Product quality and pricing & 0.08 & & & & $\mathrm{x}$ & & 0.32 \\
\hline & Diverse product variations & 0.13 & & & & & $\mathrm{x}$ & 0.65 \\
\hline & $\begin{array}{l}\text { Participation in the Meat Processing Industry } \\
\text { Association of Indonesia (NAMPAIndonesia) }\end{array}$ & 0.14 & & & & & $\mathrm{x}$ & 0.70 \\
\hline & Total & 1.00 & & & & & & 4.45 \\
\hline
\end{tabular}

Remarks: Rating: 1 = Very Small; 2 = Minor; 3 = Moderate; 4 = Large; 5 = Very Large.

Source: Primary Data (processed), 2016

Table 3. The Weighting of Weakness Factors of PT. Dagsap Endura Eatore Yogyakarta

\begin{tabular}{|c|c|c|c|c|c|c|c|c|}
\hline \multirow{2}{*}{ No } & \multirow{2}{*}{ Weakness } & \multirow{2}{*}{$\begin{array}{l}\text { Weight } \\
\text { (W) }\end{array}$} & \multicolumn{5}{|c|}{ Rating (R) } & \multirow{2}{*}{ Score $(\mathrm{W} \times \mathrm{R})$} \\
\hline & & & 1 & 2 & 3 & 4 & 5 & \\
\hline & $\begin{array}{l}\text { The requirements of products in the ASEAN market } \\
\text { that have not been met }\end{array}$ & 0.39 & & & & & $\mathrm{x}$ & 1.95 \\
\hline & Low labor cost & 0.17 & & & $\mathrm{x}$ & & & 0.51 \\
\hline & The brand is not too known by public & 0.15 & & & $\mathrm{x}$ & & & 0.45 \\
\hline \multirow{2}{*}{4} & The barriers between levels of management & 0.29 & & & & $\mathrm{x}$ & & 1.16 \\
\hline & Total & 1.00 & & & & & & 4.07 \\
\hline
\end{tabular}

Remarks: Rating: 1 = Very Small; 2 = Minor; 3 = Moderate; 4 = Large; 5 = Very Large.

Source: Primary Data (processed), 2016

was greater than a threats to the difference in the numbers of 0.59 (Table 6). The difference in this figure was obtained from the reduction of the amount of weight at opportunities with the amount of weight on the threats. While the number of internal analysis of the company strengths and weakness, it was found that PT. Dagsap Endura Eatore Yogyakarta had a greater strengths than the weakness. The results of the analysis of the business strengths and weakness, it was obtained the number of difference 0.38 with the total score of the power 4.45 minus with the total score of the weakness that was 4.07.

By knowing the difference between the results of internal and external factors of the company, it could be identified the position of PT. Dagsap Endura Eatore ASEAN Yogyakarta in the international market, as can be seen in Figure 1.
Based on SWOT quadrant Figure 1, it is shown that the position of PT. Dagsap Endura Eatore Yogyakarta is in quadrant I.

\section{Company Strategy Formulation}

Based on the analysis of internal environment and the external environment of PT. Dagsap Endura Eatore Yogyakarta, it could be undergone the approaches by using S-O strategy SWOT matrix, this strategy was based on the idea of companies by using all internal strengths of company to take advantage from external opportunities (Table 7). The objective of this SWOT matrix was to determine the alternative strategy used by PT. Dagsap Endura Eatore Yogyakarta in ASEAN entering the international market. 
Table 4. The Weighting of Opportunities Factors of PT. Dagsap Endura Eatore Yogyakarta

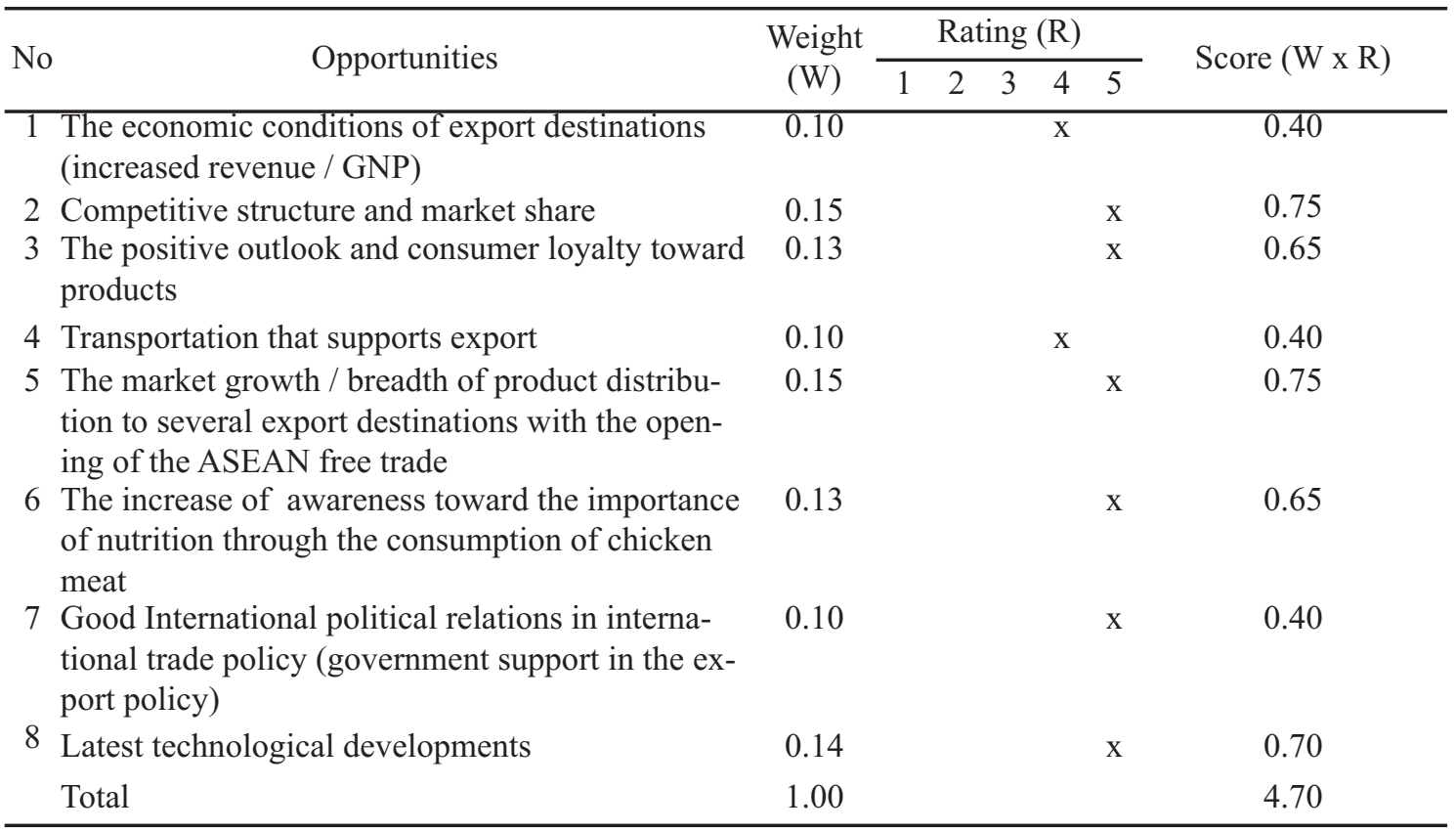

Remarks: Rating: 1 = Very Small; 2 = Minor; 3 = Moderate; 4 = Large; 5 = Very Large.

Source: Primary Data (processed), 2016

Table 5. Weighting of Threats Factors of PT. Dagsap Endura Eatore Yogyakarta

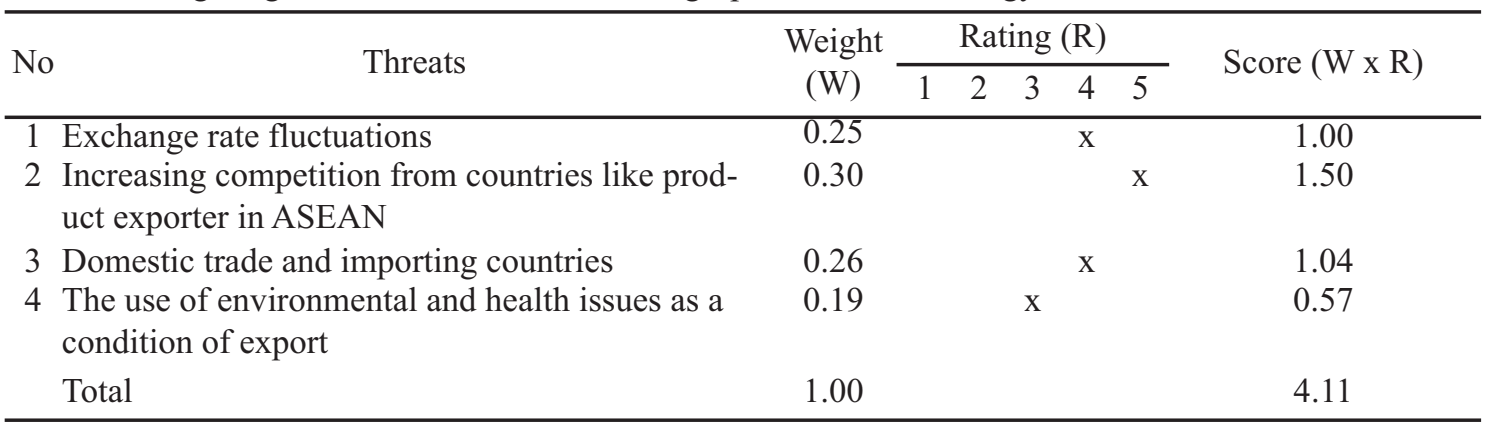

Remarks: Rating: 1 = Very Small; $2=$ Minor; $3=$ Moderate; $4=$ Large; $5=$ Very Large.

Source: Primary Data (processed), 2016

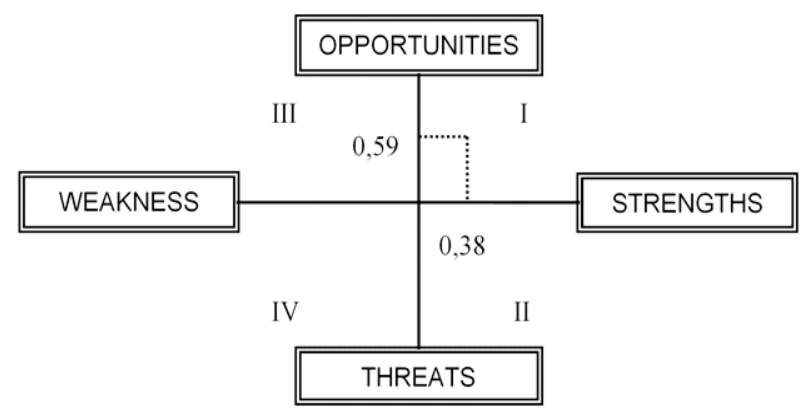

Figure 1.The position of the Company in Diagram SWOT Analysis
Table 6. Scoring Results of Internal and External Factors of PT. Dagsap Endura Eatore Yogyakarta to ASEAN international markets

\begin{tabular}{|c|c|c|c|}
\hline No & Criteria & Score & Coordinate \\
\hline & \multicolumn{3}{|l|}{ Internal Factors } \\
\hline 1 & Strengths & 4.45 & 0.38 \\
\hline \multirow[t]{2}{*}{2} & Weaknesses & 4.07 & \\
\hline & External Facto & & \\
\hline 1 & Opportunities & 4.70 & 0.59 \\
\hline 2 & Threats & 4.11 & \\
\hline
\end{tabular}

Remarks: Internal Conditions: Strengths $>$ Weaknessess (0.38) External conditions: Opportunities $>$ Threats $(0.59)$

Source : Primary Data (processed), 2016 
Table 7. Strategies Alternative Based on SWOT Matrix

\begin{tabular}{|c|c|c|}
\hline$\searrow$ & $\begin{array}{l}\text { Strengths (S) } \\
\text { 1. The ability of the production process } \\
\text { and the continuity of production } \\
\text { 2. The ability of the staff and employees } \\
\text { in carrying out the production work } \\
\text { 3. The ability of management and } \\
\text { experience in executing marketing } \\
\text { activities } \\
\text { 4. Ability in setting the market target } \\
\text { 5. Mastery of the domestic market } \\
\text { 6. The use of modern machines / semi- } \\
\text { robotic for the production of large } \\
\text { capacity } \\
\text { 7. The ability of the distribution and } \\
\text { transportation } \\
\text { 8. The quality of the products and } \\
\text { pricing } \\
\text { 9. Variations diverse product } \\
\text { 10. Participation in the Meat Processing } \\
\text { Industry Association of Indonesia } \\
\text { (Indonesia NAMPA) }\end{array}$ & \begin{tabular}{|l|} 
Weakness $(\mathrm{W})$ \\
1. The requirements for products in the \\
ASEAN market have not been met \\
2. The cost of labor was low \\
3. Barrier between management levels
\end{tabular} \\
\hline $\begin{array}{l}\text { Opportunities (O) } \\
\text { 1. The economic conditions of export } \\
\text { destinations (increased revenue } \\
\text { GNP) } \\
\text { 2. The structure of competition and } \\
\text { market share } \\
\text { 3. The positive outlook and consumer } \\
\text { loyalty to products } \\
\text { 4. Means of transport support export } \\
\text { 5. The growth of the market / distribution } \\
\text { breadth of products to some countries } \\
\text { destination with the opening of the } \\
\text { ASEAN free trade } \\
\text { 6. Increased awareness of the importance } \\
\text { of nutrition through the consumption } \\
\text { of chicken meat } \\
\text { 7. A good international political relations } \\
\text { in international trade policy (government } \\
\text { support in the export policy) } \\
\text { 8. Recent technological developments }\end{array}$ & $\begin{array}{l}\text { S-O STRATEGY } \\
\text { 1. Aggressive growth strategy (Growth } \\
\text { Oriented Strategy) } \\
\text { 2. Analyze the first ASEAN country of } \\
\text { destination to be used as a target } \\
\text { market } \\
\text { 3. Analyzing the current market trends } \\
\text { ASEAN as colors that were popular } \\
\text { in the country of export destination } \\
\text { 4. Taking into account the quality and } \\
\text { the quality of the products to be } \\
\text { marketed } \\
\text { 5. Pay attention to how the delivery of } \\
\text { goods and payment system that } \\
\text { would be used } \\
\text { 6. Thinking about the readiness of the } \\
\text { company before deciding to head } \\
\text { ASEAN export markets } \\
\text { 7. Taking into account the pricing } \\
\text { strategy } \\
\text { 8. Determine the method of payment } \\
\text { and delivery of goods to be used by } \\
\text { the company in its sales transactions } \\
\text { with customers or buyers of export } \\
\text { destinations }\end{array}$ & \\
\hline $\begin{array}{l}\text { Threats }(\mathrm{T}) \\
\text { 1. Exchange rate fluctuations } \\
\text { 2. The increased of competition from } \\
\text { exporters countries of similar products } \\
\text { in ASEAN } \\
\text { 3. The domestic trade and importing } \\
\text { countries } \\
\text { 4. The use of environmental and health } \\
\text { issues as a condition of export }\end{array}$ & & \\
\hline
\end{tabular}




\section{CONCLUSION}

PT. Dagsap Endura Eatore Yogyakarta was currently at quadrant I. The focus of strategy of PT. Dagsap Endura Eatore Yogyakarta at this situation was to utilize the strengths in order to reach out and take advantage of existing opportunities. Export strategy that should be applied by the company to enter the ASEAN international market was the aggressive growth strategy (Growth Oriented Strategy), analyzing the first destination countries of ASEAN to be used as a target market, analyzing ASEAN market trends that like the popular colors in the country of destination export, noticing to quality and the product quality to be marketed, noticing the manner in which the delivery of goods and payment system that would be used, thinking about the readiness of the company before deciding to go to the export market of ASEAN, paying attention to the pricing strategies, and determining the method of payment and delivery of goods to be used by the company in conducting sales transactions with customers or buyers of export destinations.

\section{ACKNOWLEDGEMENT}

Special thanks to head of Magister Management of Agribusiness of Faculty of Agriculture, Universitas Gadjah Mada, Dr. Slamet Hartono, SU. M.Sc, who gives the chance to build the research.

\section{REFERENCES}

Assauri, S. 1990. Manajemen Pemasaran: Dasar, Konsep, dan Strategi. Jakarta: Rajawali Press.
Charity, D. S., E. Yulianto dan Wilopo. 2016. Analisis Strategi dalam Memasuki Pasar Internasional (Studi Kasus pada PT Telekomunikasi Indonesia dalam Ekspansi di Myanmar). Jurnal Administrasi Bisnis (JAB), 32 (1): 18-26.

Darmayani, A. I., Suharyono dan Y. Abdillah. 2014. Strategi Pemasaran Kerajinan Buah Kering untuk Meningkatkan Nilai Ekspor pada UD. Indo Nature, Lombok-NTB. Jurnal Administrasi Bisnis (JAB), 11(1): 1-10

Gaspersz, V. 2014. Apakah Indonesia Siap Menghadapi Pasar Bebas ASEAN AFTA. [online] Available at: http://ekonomi.kopasiana.com/ bisnis/ [Accessed 11 Nov. 2015].

Ichwanda, F. I., Z. Arifin dan E. Yulianto. 2015. Analisis Strategi Pemasaran untuk Meningkatkan Volume Penjualan Ekspor (Studi pada PT Petrokimia Gresik). Jurnal Administrasi Bisnis (JAB), 24(1): 1-9.

Marhendra, A. V. H., Z. Arifin dan Y. Abdillah. 2014. Analisis Dampak Kebijakan Pembatasan Kuota Impor Sapi terhadap Kinerja Perusahaan (Studi Kasus pada PT. Great Giant LiveStock (GGLC), Lampung Tengah-Lampung). Jurnal Administrasi Bisnis (JAB), 13(1): 1-8.

Sadaghiania, J. S., N. A. Dehghanb and K. N. Zandc. 2011. Impact of International Market Entry Strategy on Export Performance. The Journal of Mathematics and Computer Science (TJMCS), 3(1): 53-70.

Sopian. 2010. Strategi Pemasaran Jasa Pest Control pada PT. " $X$ ” Yogyakarta. Yogyakarta: Universitas Gadjah Mada. 